\title{
Punctuated growth of an accretionary prism and the onset of a seismogenic megathrust in the Nankai Trough
}

\author{
Gaku Kimura ${ }^{1 *}$, Hiroaki Koge ${ }^{2}$ and Takeshi Tsuji
}

\begin{abstract}
Ocean drilling in the Nankai Trough forearc suggests a new scenario for the evolution of the Nankai subduction zone. Continuous subduction since the Late Cretaceous has been a common tectonic scenario, although the plate subduction was transferred from the Pacific Plate to the Philippine Sea Plate during the Miocene. Seismic reflection studies coupled with drilling have demonstrated that two episodes have controlled the recent evolution of the Nankai forearc: a resurgence of subduction at $\sim 6 \mathrm{Ma}$ after cessation since $\sim 12 \mathrm{Ma}$ and rapid growth of the accretionary prism since $\sim 2$ Ma because of the influx of large amounts of terrigenous sediments from the Japan Alps in central Japan. Both episodes were synchronous with large-scale plate reorganizations. The westward subduction of the Philippine Sea Plate initiated both in the Ryukyu and the Philippine trenches at $\sim 6 \mathrm{Ma}$. Rifting in the Okinawa and Mariana troughs started at $\sim 6 \mathrm{Ma}$. Compressive tectonics in northeast Japan started at $\sim 3-2 \mathrm{Ma}$, and resultant mountain building with active surface erosion commenced in central Japan at $\sim 2 \mathrm{Ma}$. This recent compressive tectonic phase might be due to the initiation of convergence of the Amurian Plate with the Okhotsk or North American Plate along the eastern margin of the Japan Sea. In addition to this event, the strong collision and indentation of the Izu-Bonin Arc since $\sim 2.5 \mathrm{Ma}$ was also enhanced in central Japan.
\end{abstract}

Keywords: Nankai Trough, Accretionary prism, Seismogenic zone, Forearc basin, Subduction zone, Megathrust, Collision, Amurian Plate, Okhotsk Plate, Kumano Basin

\section{Introduction}

The Nankai Trough in southwest Japan is among the most thoroughly studied subduction zones with many geological and geophysical investigations. Geological studies have suggested that subduction and accretion have been continuous since the late Cretaceous (e.g., Taira et al. 1988). Meanwhile, several global geologic events have occurred since then, including the early Cenozoic global reorganization of plate motions (e.g., Seton et al. 2015), back-arc spreading in the western Pacific margin (Karig 1971), and intra-continental deformation caused by the India-Asian collision (Tapponnier et al. 1982). Their effects on the subduction processes must be recorded in accretionary complexes, but the resulting phenomena of

\footnotetext{
* Correspondence: gkimur0@kaiyodai.ac.jp

${ }^{1}$ Department of Marine Environment and Resources, Tokyo University of Marine Science and Technology, Shinagawa, Minato-ku, Tokyo 108-8477, Japan

Full list of author information is available at the end of the article
}

each event remains unclear. Finding such a causal relationship is difficult for the ancient geological record, but easier for the recent past.

The recent drilling campaign by the Integrated Ocean Drilling Program (IODP) in the Nankai Trough (Tobin and Kinoshita 2006) has provided a clue to its Cenozoic tectonic history (e.g., Strasser et al. 2009; Kimura et al. 2011; Clift et al. 2013; Pickering et al. 2013; Kimura et al. 2014; Moore et al. 2015; Boston et al. 2016;Underwood 2018). These results demonstrate that accretion in the Nankai Trough has not been constant as previously thought (e.g., Kimura et al. 2005) but rather has been episodic even in the recent past. The present tectonic framework was initiated at $\sim 2 \mathrm{Ma}$ in southwest Japan in association with the rapid influx of sediment into the Nankai Trough and the Kumano forearc basin from the Japanese islands. Reviewing the in-land geology and the result of the drilling, Kimura et al. (2014) and Tsuji et al. (2017) suggested that subduction in the Nankai Trough 
resurged at $\sim 6 \mathrm{Ma}$ after a long cessation since $\sim 12 \mathrm{Ma}$. Underwood (2018) suggested a switch in subducting plate from the Pacific to the Philippine Sea Plate during $\sim 10$ to $5 \mathrm{Ma}$. These recent interpretations challenge the traditional tectonic model of the continuous subduction (e.g., Kimura et al. 2005), which are mainly based on in-land geological information.

In this study, we interpret seismic profiles of the northern edge of the Kumano forearc basin, discuss the Nankai forearc evolution, and propose their regional linkage to the plate tectonic framework.

\section{Nankai Trough geological setting}

The Nankai forearc is separated into two tectonic domains: the inner and outer wedges that are separated by a transitional thrust zone of the outer ridge or trench slope break (Kimura et al. 2007), termed the Kumano
Basin Edge Fault Zone (KBEFZ: Fig. 1, Martin et al. 2010). The accretionary outer wedge is composed of previous trench-filling turbidites and Shikoku Basin sediments of the Philippine Sea (PS) Plate, now subducting at a rate of $\sim 58.4 \pm 1.4 \mathrm{~mm} / \mathrm{a}$ (DeMets et al. 2010). Drilling into the slope sediments and the accretionary prism of the outer wedge has documented the rapid growth of the accretionary prism since $\sim 1.95-2.0 \mathrm{Ma}$ (Screaton et al. 2009; Strasser et al. 2009; Kimura et al. 2011). Underplating of the clayey sediments of the Shikoku Basin also appears to have promoted the rapid growth of the lower section of the outer wedge, characterized by a seismic low-velocity zone and slow earthquakes (Kamei et al. 2013; Park et al. 2010).

The inner wedge comprises the accretionary prism and overlying sediments (Saffer et al. 2009; Gulick et al. 2010; Moore et al. 2015; Boston et al. 2016). The age of

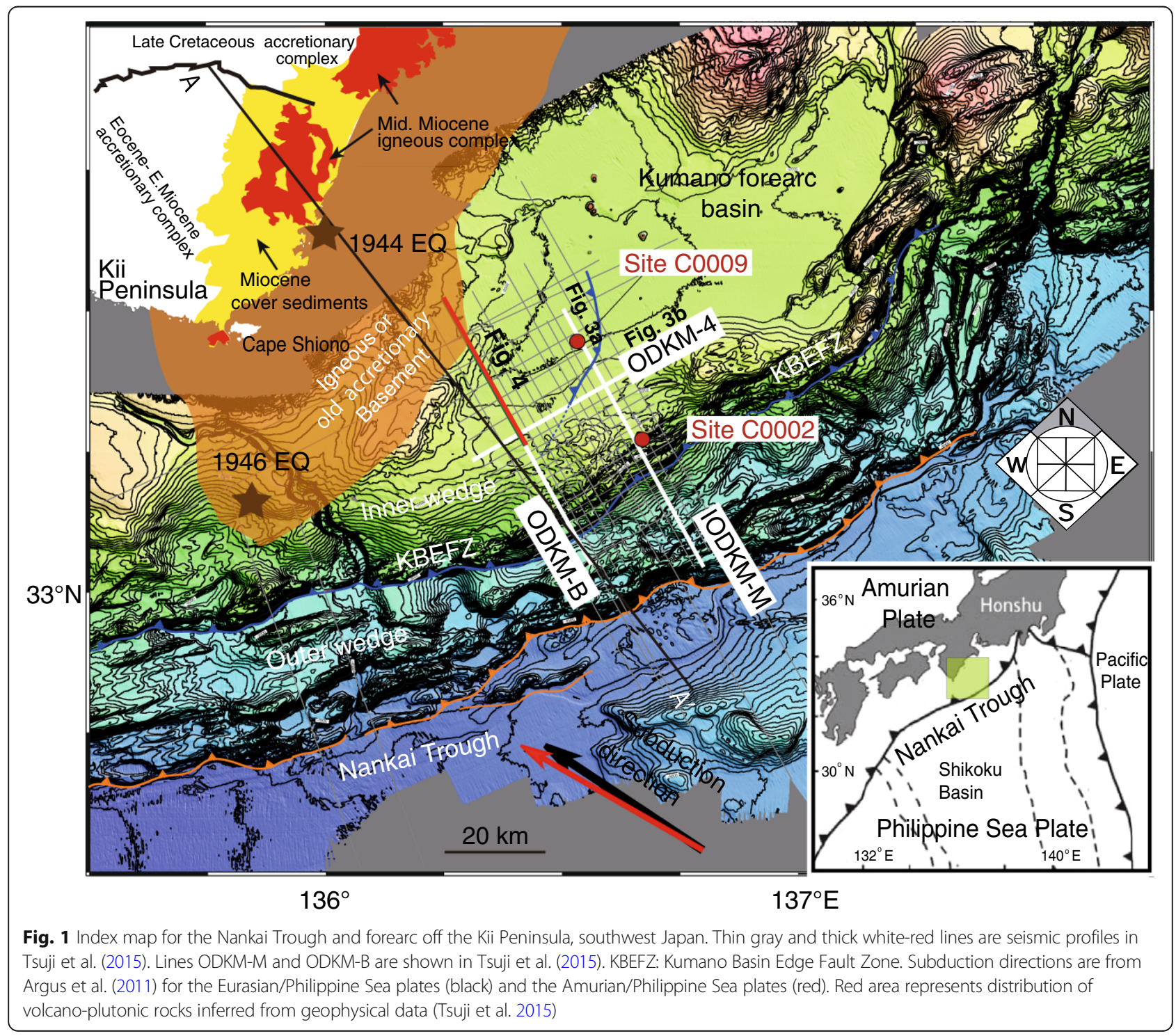


the accretionary prism, just beneath 5.6 m.y. cover sediments, is $\sim 7.9-8.1 \mathrm{Ma}$ at the C0009 drill site and $5.0 \mathrm{Ma}$ at the C0002 drill site (Fig. 1; Saffer et al. 2009; Moore et al. 2015). The age increases with depth at C0002 to $\sim 10 \mathrm{Ma}$. These data suggest that accretion started at the timing of the unconformity around $\sim 6 \mathrm{Ma}$ (between $\sim 7.9$ and $\sim 5.6 \mathrm{Ma}$ ). Slope and forearc basin sediments then began to bury the prism rocks. The forearc basin was rapidly filled after $\sim 2.0$ Ma with a northward onlapping unconformity and northward migration of the depocenter above the underlying slope sediments (Gulick et al. 2010; Moore et al. 2015; Boston et al. 2016). This swift development of the forearc basin was caused by the rapid KBEFZ uplift which was caused by the accretion of trench-filling sediments supplied by mountain building on land to the trench (Kimura et al. 2008).

The on-land geology of the Kii Peninsula to the north of the Kumano Basin comprises three assemblages: a Jurassic to lower Miocene basement accretionary complex, upper Cretaceous to middle Miocene cover sediments, and middle Miocene igneous rocks (e.g., Suzuki 2012). The southern peninsula constitutes an Eocene-Oligocene to lower Miocene accretionary prism, middle Miocene shallow marine to lagoon sediments partly including coal beds, and middle Miocene igneous rocks. Middle Miocene rapid uplift is well documented from the abrupt change in the depositional environment from submarine to near-shore lagoon deposits (Hisatomi 1981). After the intrusion and eruption of a large caldera acidic volcano at $\sim 15-13 \mathrm{Ma}$ (e.g., Kimura et al. 2005; Miura and Wada 2007), magmatic-tectonic activity ceased. Between $\sim 12$ and $\sim 6 \mathrm{Ma}$, no subduction-related magmatic activity was recorded in southwest Japan, and the forearc region was broadly uplifted (e.g., Kimura et al. 2014).

This event is consistently recorded as the rapid exhumation of the Cretaceous accretionary prism (Tagami et al. 1995). Kimura et al. (2014) suggested that the subduction cessation might have been caused by the collision of the northern extension of the buoyant Izu-Bonin Arc, as first suggested by Marshak and Karig (1977).

\section{Methods/Experimental}

To elucidate the initiation of the slope and forearc basins of the Nankai, we reexamined multichannel seismic reflection data and core data acquired by the IODP Nankai Trough Seismogenic Zone Experiments (NantroSEIZE) project in the Nankai Trough off the Kii Peninsula, southwest Japan.

\section{Seismic data}

We used multichannel seismic reflection data acquired during cruise ODKM of the R/V Polar Princess in 2003, which employed a tuned airgun array with a total volume of $\sim 70 \mathrm{~L}$ fired at $50 \mathrm{~m}$ intervals and a streamer $6 \mathrm{~km}$ in length with 480 receivers. These seismic data were obtained in a dense orthogonal geometry in the Nankai accretionary prism off Kumano, and the survey lines extended near the coast of the Kii Peninsula (Fig. 1). We focused on three lines: the northeast-trending ODKM-4 and northwest-trending ODKM-M and ODKM-B (Figs. 1 and 2), which were reported by Tsuji et al. (2015). Data processing for the 2D seismic data included filtering, velocity analysis, stacking, deconvolution, and post-stack migration. To extract horizons of the top surface of the accretionary prism and reflectors in the forearc sediments from the intersecting seismic reflection lines, we did not apply depth conversion to the time-domain seismic profiles. The paucity of reflectors within the accretionary prism prevented us from estimating seismic velocities for a depth conversion.

\section{Core data}

We used age data from cores, cuttings, and logs collected at IODP Sites C0002 and C0009 (Ashi et al. 2009; Underwood and Moore 2012; Expedition 316 Scientists 2009; Expedition 319 Scientists 2010). Moore et al. (2015) reviewed the ages from the $\mathrm{C0009}$ and $\mathrm{C0002}$ sites in the Kumano Basin (Fig. 1) and inferred the evolving process of the Nankai forearc basin from a seaward-dipping slope to a basin to a mature modern basin, particularly focusing on the tectono-stratigraphic evolution since $\sim 2 \mathrm{Ma}$. We expanded upon the results of stratigraphic correlation on the seismic profile of ODKM-M-which was nearly the same line as IL2535 of the 3D survey of Moore et al. (2009) - to reflectors on the ODKM-B and those on ODKM-4 (Figs. 2, 3, 4, and 5).

\section{Results}

The evolving history of the central to southern Kumano basin is well reconstructed on the basis of seismic data calibrated by data from the $\mathrm{C0002}$ and $\mathrm{C0009}$ drill sites (Saffer et al. 2009; Gulick et al. 2010; Martin et al. 2010; Moore et al. 2015; Boston et al. 2016). Comparing the results of these investigations, we reexamined the northern edge of the Kumano Basin (Figs. 2, 3, 4, and 5) where the oldest section of the slope sediments has been reported above the accretionary prism (Tsuji et al. 2015). The age constraints of the sediments are poor since neither drilling nor coring have been conducted in the region. Although direct evidence of the age of the sediments is not available, an age inference was possible because the geologic setting was similar to that of the drilling site C0009 (Figs. 1 and 2), which was located on a northern piggyback slope basin of a reactivated northeast-trending fault-bend fold (Figs. 1 and 2; Tsuji et al. 2015; Moore and Strasser 2016). The stratigraphy 


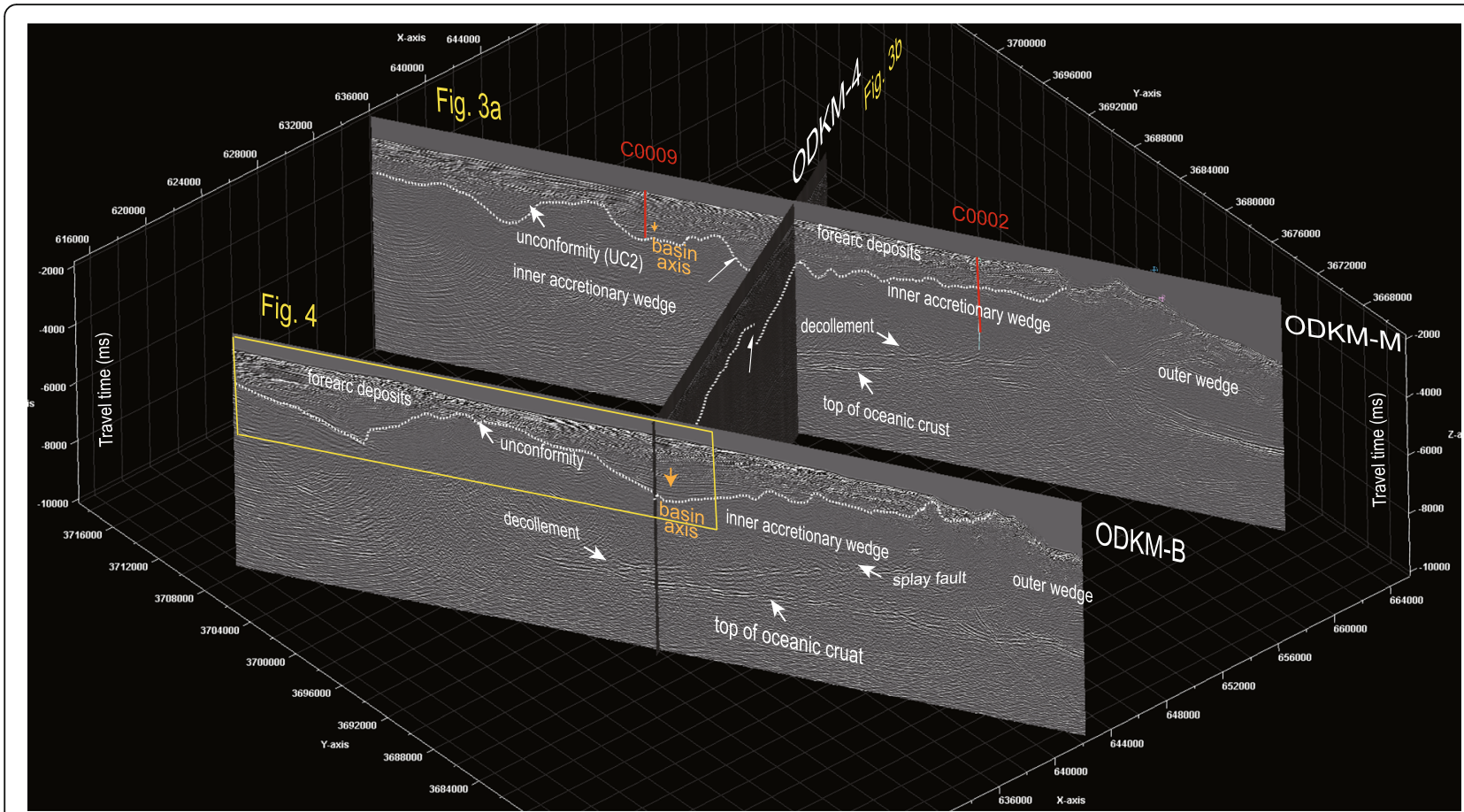

Fig. 2 Space relationship among three seismic reflection profiles: ODKM-M, OKDM-4, and ODKM-B. ODKM-M and ODKM-4 are shown in Fig. 3. The northern part of ODKM-B is shown in Fig. 4. Drilling sites C0002 and C0009 are shown on the profile of ODKM-M. Note a piggyback synclinal basin (orange arrow) behind the northeast-trending fault-bend anticline, as shown by Tsuji et al. (2015)

with a clear unconformity of KL (Figs. 3 and 4) separating the upper forearc basin-filling sediments and the lower slope basin deposits (Moore and Strasser 2016) are clearly correlated. However, the KL reflector of the unconformity does not denote a synchronous reflector as documented by drilling (Moore et al. 2015). A continuous reflector of a layer within the forearc basin-filling sediments is possible to correlate as a synchronous surface, as is well documented by coring (e.g., Strasser et al. 2009; Moore et al. 2015).

Figures 3 and 4 show a hypothetical correlation between $\mathrm{C0009}$ and a site on the seismic profile of ODKM-B through ODKM-4. A key reflector is K4 (Figs. 3 and 4), which is a broadly traceable layer within the Kumano Basin sediments and abuts the unconformity surface of US1 (KL of Moore et al. 2015, S2 of Saffer et al. 2009), as shown in Fig. 4. The age of the unconformity of US 1 progressively becomes younger toward the north from $\sim 1.6 \mathrm{Ma}$ at C0002 to $\sim 0.9 \mathrm{Ma}$ at C0009 (Moore et al. 2015), and the forearc deposits lap onto the unconformity surface. The US1 unconformity progresses to the northern edge of the Kumano Basin, as observed in Fig. 4.

The east-northeast-trending seismic profile of ODKM4 is orthogonal to the north-northwest-trending profiles of ODKM-M and ODKM-B and parallel to the strike of the Nankai Trough (Figs. 1 and 2). These arrangements are the same in the $3 \mathrm{D}$ volume of investigation (Moore et al. 2009). The KL (US1) unconformity on the east-northeast-trending profiles is nearly parallel to the beddings of both the upper and lower sediments (Moore et al. 2015). This fact is the key to correlating the age of the KL unconformity to the US1 unconformity on ODKM-B via ODKM 4 (Figs. 2, 3, and 4) and the US3 unconformity between the slope deposits and basement of the accretionary prism (Figs. 2, 3, and 4). The start of deposition (US3) in the slope basin above the accretionary prism suggests an initiation of accretion, as is well documented in the modern Nankai frontal prism (Screaton et al. 2009; Strasser et al. 2009).

Figure 4 presents a seismic reflection image (Tsuji et al. 2015) of the northern margin of the Kumano Basin. Ages are extrapolated from C0009 and depicted along the right margin of Fig. 4b.

\section{Cover sediments}

Cover terrigenous sediments and a transparent accretionary prism are recognized as introduced (Figs. 2, 3, and 4). Three sedimentary units (units 1-3) are separated by the unconformities of US1 and 2. The age of US1 might be $\sim 1.0 \mathrm{Ma}$, but it becomes progressively younger northward because unit 1 gradually laps onto US1. Moore et al. (2015) suggested that the onlap unconformity started from the southern margin of the 


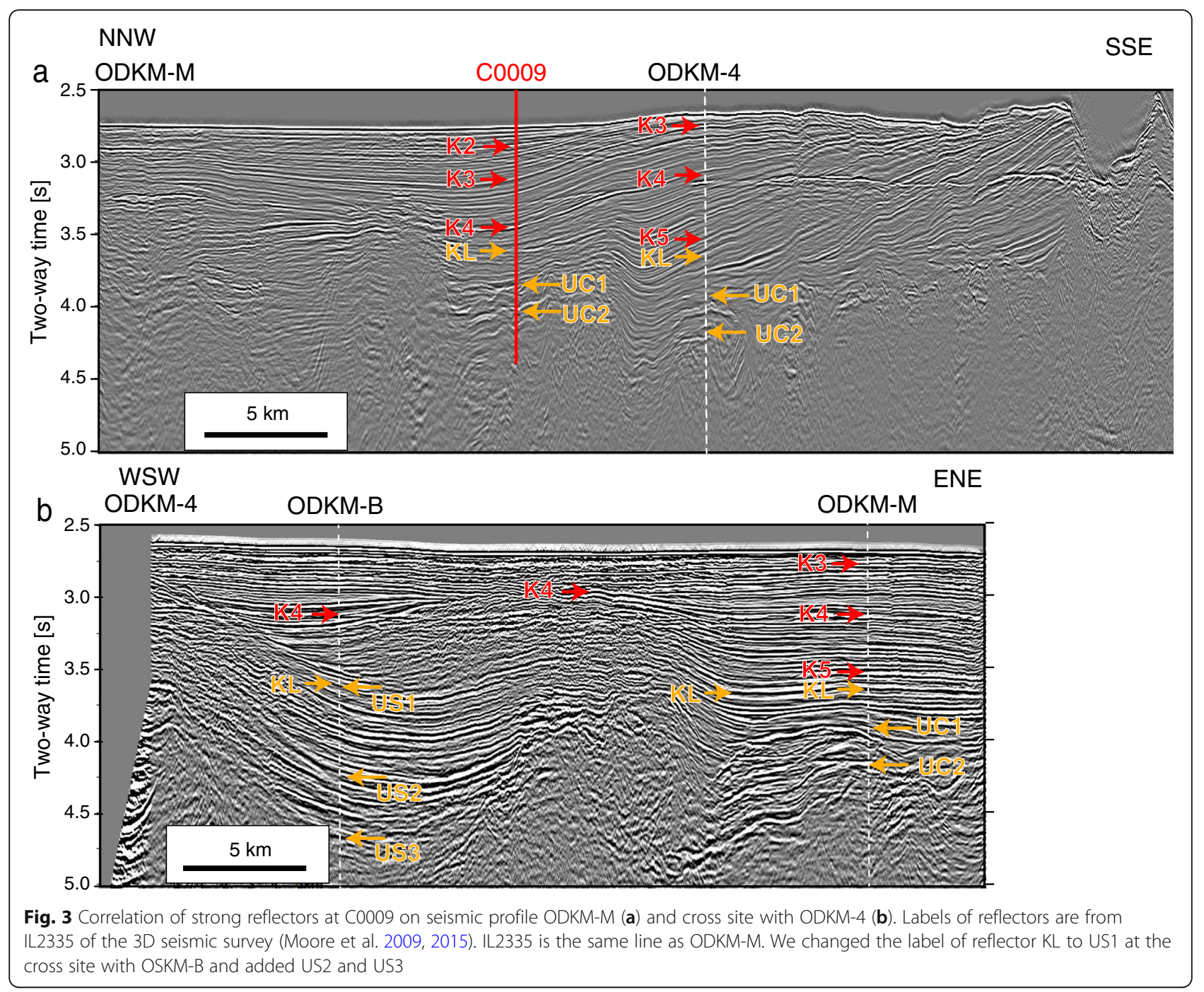

forearc basin at $\sim 2 \mathrm{Ma}$ and migrated northward. The profile of ODKM-B shows the presently ongoing US1 location (Fig. 4).

The age of US2 (as shown in Fig. 4) was $3.7 \mathrm{Ma}$, and the seismic profile showed an angular unconformity with onlapping. Unit 3 was the lowest sediment between US2 and US3, and plant fragments were found at C0009 (Saffer et al. 2009). The age was uppermost Miocene to lower Pliocene. The age of US3 was $\sim 6 \mathrm{Ma}$ on the upper Miocene accretionary prism (Saffer et al. 2009; Moore et al. 2015). The age of the sediments of unit 3 above the accretionary prism (shown on the left side of Fig. 4) was unclear because the direct correlation of a synchronous layer was difficult on the profile. However, age inference may be possible since the setting of the basin was similar to that at site C0009, which was a piggyback basin behind the northeast-trending fault-bend anticline (Figs. 1 and 2; Tsuji et al. 2015), and the basin-filling sequences were composed of three units separated by three unconformities similar to those at $\mathrm{C0009}$ (Fig. 5). Thus, we infer US3 may be $\sim 6 \mathrm{Ma}$ as well as the others.

\section{Basement and accretionary prism}

The lithology of the basement (as shown in the lower left of Fig. 4) may be different from the accretionary prism because the US3 unconformity between the sediments, and the basement was intensively reflective with a positive anomaly suggestive of hard rocks in the basement (Tsuji et al. 2015). Tsuji et al. (2015) suggested the middle Miocene igneous rocks exposed on land or the older Eocene-Lower Miocene accretionary complex for the basement. The composition of the antiformal accretionary prism to the south of the back-thrust was unknown, and the possibility of mud diapir uplift was suggested in the northern edge of the Kumano basin to the east of this region (Morita et al. 2004). 


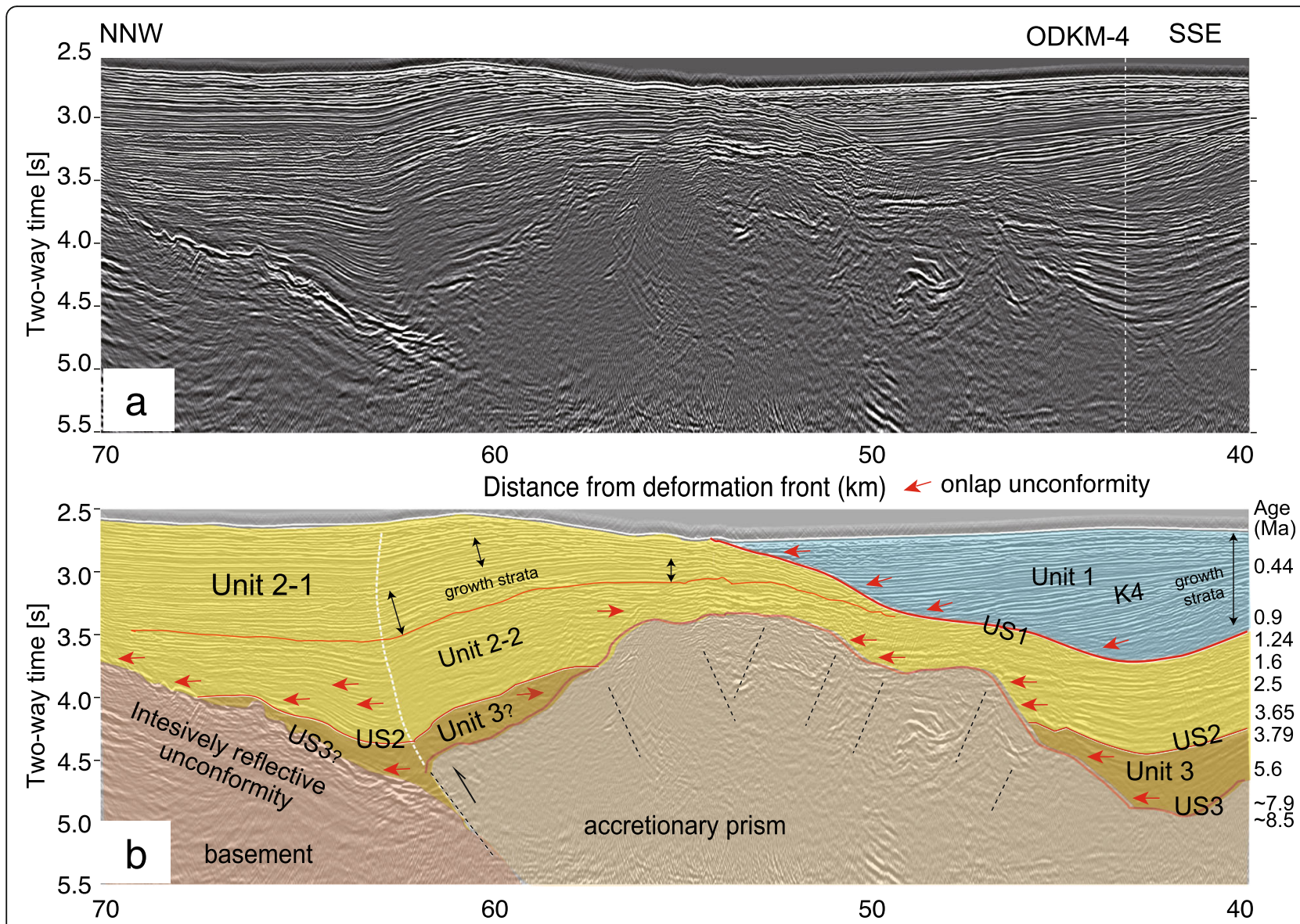

Fig. 4 A seismic reflection profile of ODKM-B (Tsuji et al. 2015) (a) and interpretation (b). The location for the profile is shown in Fig. 1. Unconformities US1 and 2 and US3 on the right side of the figure are correlated to S2, UC1, and UC2 of Saffer et al. (2009) and KL, UC1, and UC2 of Moore et al. (2015), respectively, on the basis of the relayed correlation in Fig. 3. Ages are from Saffer et al. (2009) and Moore et al. (2015). A red arrow shows an onlap unconformity. Growth strata with arrowed line are also shown in this figure

\section{Initiation of accretion, slope deposition, and sedimentation in the forearc basin}

The structure of the northern edge of the Kumano Basin (Fig. 5) indicates the initiation of accretion and the Kumano basin as follows:

1) Accretion of $\sim 8$ m.y. old sediments started at $\sim 6 \mathrm{Ma}$ with the deposition of cover slope sediments. The slope sediments also started to cover the stiff basement of Eocene to early Miocene age or the igneous rocks of the middle Miocene (Fig. 5a).

2) At $\sim 3.7 \mathrm{Ma}$, a regional sedimentary break (US2) occurred with tectonic tilting in the forearc (Fig. 5b). The growth of the accretionary prism (Fig. 5a) might be related to this unconformity. A back-thrust of the accretionary prism occurred along the northern edge (Fig. 5a).

3) Slope deposition (unit 2-2) continued without tectonic activity from $\sim 3.7$ to $1.3 \mathrm{Ma}$ (Fig. $5 \mathrm{~b}$ ) along the northern edge of the forearc. The growth of the outer wedge and forearc deposition around the KBEFZ started at $~ 2 \mathrm{Ma}$, as noted by Strasser et al. (2009) and Moore et al. (2015).

4) The reactivated deformation of the accretionary prism with continuous slope deposition occurred later than $\sim 1.3 \mathrm{Ma}$ (Fig. 5c). The growth strata might have been associated with uplift of the accretionary prism (Fig. 5c). The anticlinal uplift of the accretionary prism with slope sediments caused erosion in place (US1), and a subsurface slope might have appeared (Fig. 5c).

5) Kumano Basin deposition started at $\sim 2 \mathrm{Ma}$ around the southern margin of the inner wedge and reached to the northern margin of the Kumano Basin at $~ 0.9 \mathrm{Ma}$; onlap sedimentation still continues along the northern margin (Fig. 5c).

6) The accretionary prism thrust upwards onto the basement (Fig. 5), and unit 3 intervened along the thrust. On the basis of evolving history, the backthrusting with $\sim 2 \mathrm{~km}$ displacement and $\sim 1 \mathrm{~km}$ uplift was inferred (Fig. 5), assuming $\mathrm{P}$ wave velocity of the sediments in such a depth of $\sim 2 \mathrm{~km} \mathrm{~s}^{-1}$, as 


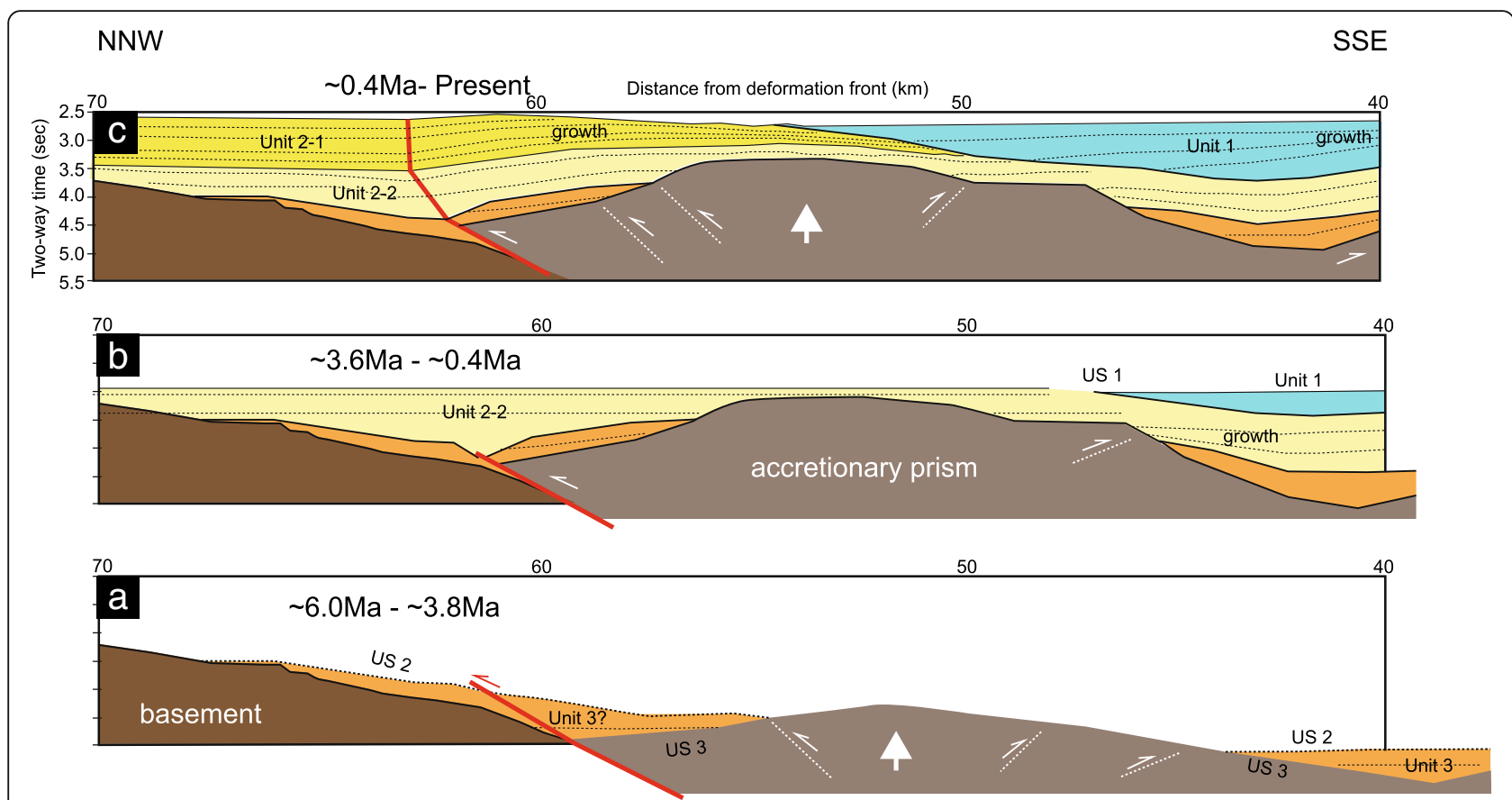

Fig. 5 The schematic diagrams indicate structural evolution at the region around MCS line ODKM-B of the northern margin of the Kumano forearc basin from $\sim 6 \mathrm{Ma}$. Ages from (a) to present (c) are on the basis of Fig. 5. Note that the sedimentation, unconformities, and deformation are related to each other and that structuring might be currently occurring. a The back-thrust started with the growth of accretionary prism. First slope sediments (Unit 3) were involved into the deformation. b After the first settlement of the anticlinal crest of the accretionary prism, slope sediments deposited and covered the accretionary prism. A part of the forward thrust (white dotted thrust) tilted unit 2-2. c The northern edge of the Kumano Basin was reactivated $\sim 4.0 \mathrm{Ma}$ and promoted the deformation of the accretionary prism, tilting of the older slope sediments, and developed the growth strata of the forearc basin deposits. The reactivation of back-thrust and the doming of the anticlinal crest took place

commonly observed (Moore et al. 2015; Chhun et al. 2018). The thrust changed to a synclinal fault-bend-fold into unit 2 (red line in Fig. 5c). Strata of unit 1 tilt northward gently with ascension, suggesting continuous growth and depocenter migration of the forearc basin since $\sim 2 \mathrm{Ma}$, as Moore et al. (2015) suggested.

\section{Discussion}

We discuss the regional tectonic significance of the well-recorded unconformities and tectonic events previously described and their relationship to the onset of the seismogenic megathrust in the Nankai Trough.

\section{Subduction initiation of the PS plate at $\sim 6 \mathrm{Ma}$}

An age of $\sim 6 \mathrm{Ma}$ for the initiation of accretion with back-thrusting upon the stiff basement (Figs. 4b and 5a) suggests that subduction of the PS Plate resurged after a long cessation since $\sim 12$ Ma (Fig. 6: Kimura et al. 2014; Tsuji et al. 2015). The main part of the Kii Peninsula appears to be composed of the middle Miocene volcano-plutonic rocks related to the collision of the ancient Izu-Bonin arc and the active Shikoku Basin (Kimura et al. 2014). Simplified profiles at $\sim 12 \mathrm{Ma}$ and $\sim 6 \mathrm{Ma}$ are shown in Fig. 6.
The subduction cessation at $\sim 12 \mathrm{Ma}$ might have been due to the loss of slab pull force resulting from the collision of the buoyant arc and the hot back-arc Sikoku basin. The subduction resurgence at $\sim 6 \mathrm{Ma}$ may be related to cooling and densification of the PS Plate, which was once stacked beneath southwest Japan (Fig. 6). Subduction resurgence is also suggested by the resurgence of calc-alkaline igneous activity in southwest Japan (Kamata and Kodama 1999; Kimura et al. 2005). Kimura et al. (2005) inferred that the subduction of the PS Plate continued between 12 and $6 \mathrm{Ma}$, although the subduction decelerated because the alkaline basalt activity during that period would be ascribed to the subduction. However, Sakuyama et al. (2009) investigated the alkaline basalts in northern Kyushu and concluded that the activity is related to a mantle plume broadly upwelled in eastern Asia rather than subduction, as suggested by Tatsumi et al. (1990). The broad mantle plume upwelling in east Asia was recently thought to be a result of mobilized regional asthenospheric dynamics caused by the India-Asia collision (Jolivet et al. 2018).

The subduction of the PS Plate in the Nankai Trough must be interpreted within a regional plate tectonic framework. Since the late 1990s, new geodetic data using Global Positioning System (GPS) have been incorporated 


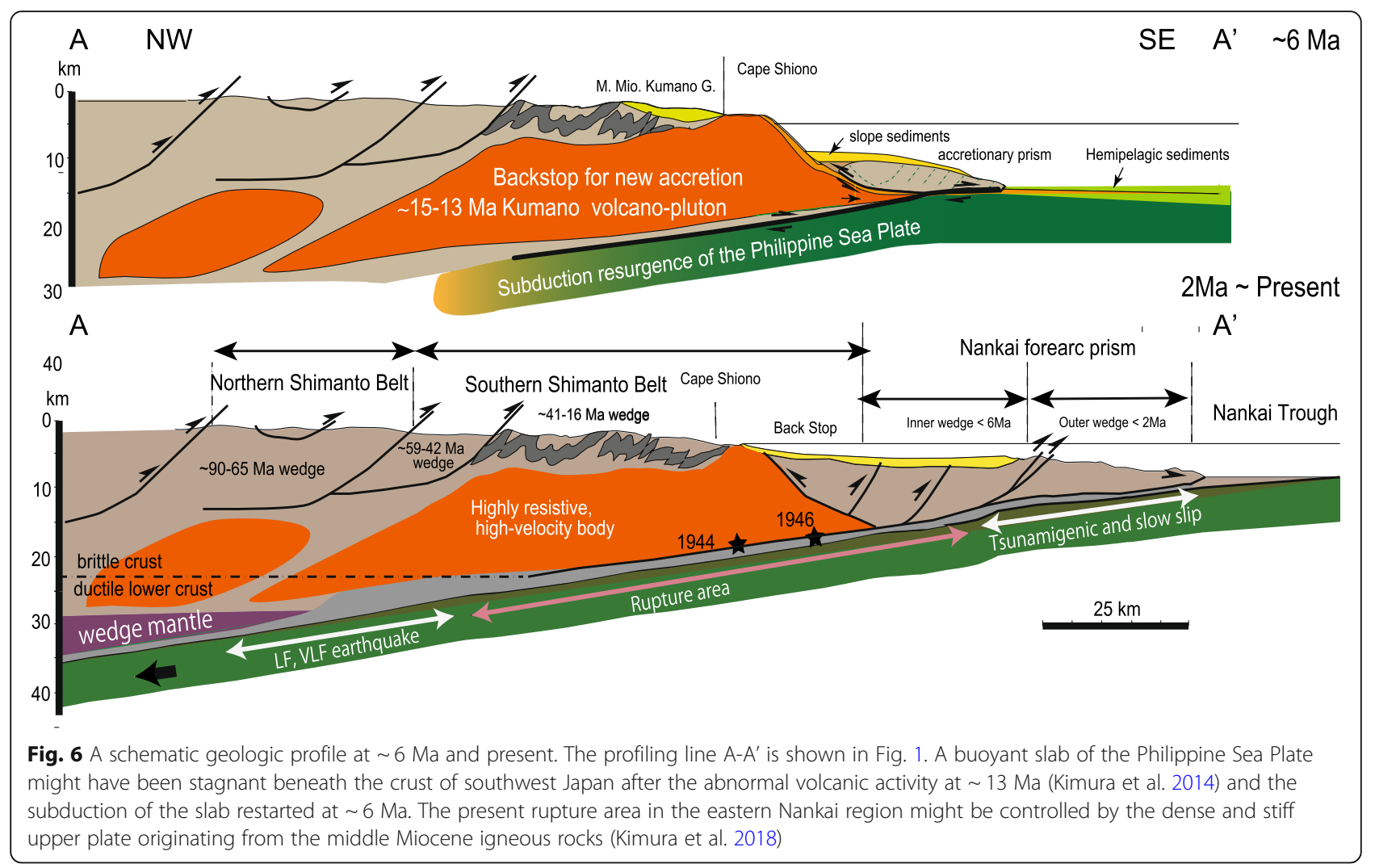

to reconstruct the plate kinematics, although the timescale is different neither from a traditional geological timescale nor an earthquake slip vector with a hypothesized recurrence time. However, combining these different data sets is useful to infer the plate motion, particularly with respect to the Asian continent. The recent revision of plate kinematic models of MORVEL (DeMets et al. 2010) or NNR-MORVEL56 (Argus et al. 2011) is a workable hypothesis.

The relative plate motion from NNR-MORVEL56 (Fig. 7) demonstrates that the PS Plate subducts beneath the Amurian Plate to the northwest in the Nankai Trough, the Yantz Plate to the west along the Ryukyu Trench, and the Sunda Plate along the Philippine Trench at present (Fig. 7). The Okinawa Trough, the active back-arc rift of the Ryukyu arc, landing both on Kyushu and Taiwan, appears to be formed by suction force resulting from trench retreat caused by slab pull force of the old, cold, and dense west Philippine Sea part of the PS Plate (e.g., Kamata and Kodama 1999; Heuret and Lallemand 2005). A recent active rift is inferred to have started at $\sim 6 \mathrm{Ma}$ with the clockwise rotation of Ishigaki Island. Rifting in the northern Kyushu also started at 6-5 Ma (Kamata and Kodama 1999). The Taiwan and the Luzon islands on the PS Plate overthrust upon the continental crust, as first noted by Suppe (1981), whereas the PS Plate subducts beneath the Sunda Plate in the Philippine Trench (Fig. 7). Hall (2002) showed that the trench was already established at $\sim 5 \mathrm{Ma}$. Relative PS Plate motion with respect to the Yantz and Sunda plates is currently faster than $90 \mathrm{~mm} \mathrm{y}^{-1}$ (Fig. 7; DeMets et al. 2010). These parts of the PS Plate are as old as the late Cretaceous to Eocene and require a sufficient westward and downward driving force of slab pull (Faccenna et al. 2017). The $\sim 6 \mathrm{Ma}$ initiation of the PS Plate subduction in the Nankai Trough appears to be derived from and associated with the westward subduction along the Ryukyu and Philippine trenches.

Another related event at $\sim 6 \mathrm{Ma}$ is the rifting initiation of the Mariana Trough (Hussong and Uyeda 1982; Yamazaki et al. 2003). The rifting has been interpreted as an anchored trench model and westward absolute motion of the PS Plate (Uyeda and Kanamori 1979). Such a relationship is well documented from the relative PS Plate motions with respect to its surroundings (Fig. 7). Recently, Faccenna et al. (2017) suggested that the Izu-Bonin-Mariana Trench switched from trench retreat to trench advance as a result of the slab pull force of the PS Plate along the Ryukyu Trench sometime between 10 and $5 \mathrm{Ma}$. We suggest that, if the timing of the switch was $\sim 6 \mathrm{Ma}$, geological observations both on land and in the subsea forearc should be consistent with this inference. The investigations of seismic tomography around the PS Plate also present a key role in reconstructing the 


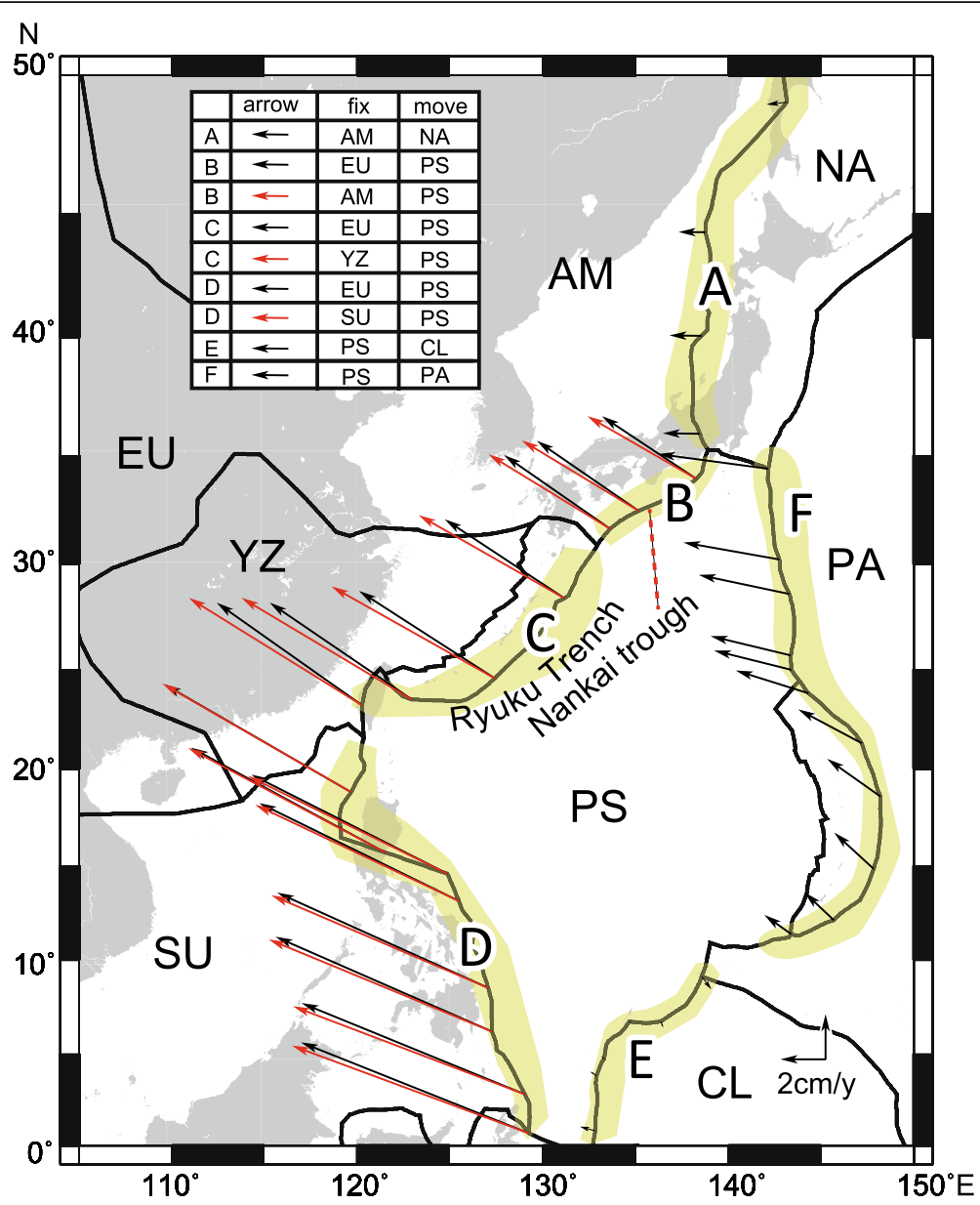

Fig. 7 A model of the relative plate motions around Philippine Sea Plate and Nankai Trough. These were calculated from the NNR-MORVEL56 models (Argus et al. 2011). AM Amurian Plate, NA North America Plate, EU Eurasia Plate, YZ Yantz Plate, PS Philippine Sea Plate, SU Sunda Plate, CL Caroline Plate, PA Pacific Plate, A Eastern Margin of the Japan Sea, B Nankai Trough, C Ryukyu Trench, D Manila and Philippine Trenches, E Yap and Palau Trenches, F Izu-Bonin-Mariana Trenches. Note that the Philippine Sea Plate is intensively driven by west-northwest-ward subduction. Plate boundaries are not defined by specific faults but zoned, thus shown in the shaded area

tectonic history of the Nankai Trough. Wu et al. (2016) presented a precise reconstruction of the subducted slab of the PS Plate in the Nankai Trough and the Ryukyu and Philippine trenches. Considering the reconstructed plate kinematics based on a GPS data set (Argus et al. 2011), a $700 \mathrm{~km}$-long slab of PS Plate beneath the East China Sea (Wu et al. 2016) can be explained largely by convergence between the Yantz and PS plates for $\sim 6 \mathrm{Ma}$ with the $\sim 90 \mathrm{~km} \mathrm{my}^{-1}$ and spreading rate of the Okinawa Trough and a trench retreat of $\sim 25 \mathrm{~km} \mathrm{my}^{-1}$ in the Ryukyu Trench (Argus et al. 2011). The 300$400 \mathrm{~km}$-long slab of the PS Plate beneath southwest Japan is also consistent with northwestward subduction at a rate of $\sim 60 \mathrm{~km} \mathrm{my}^{-1}$ between the Amurian and PS plates (Argus et al. 2011).

The reason for the subduction starting at $\sim 6 \mathrm{Ma}$ is unclear, but recently Faccenna et al. (2017) suggested that the force of the slab pull of the PS Plate in the West
Philippine Sea may have been beyond the gravitational stability caused by the cooling and densification.

\section{Modification of tectonic framework and mountain building in central Japan at $\sim 2 \mathrm{Ma}$}

The rapid sediment influx to both the Nankai Trough and forearc Kumano Basin and the resultant fast growth of the Nankai forearc started at $\sim 2 \mathrm{Ma}$. The sediment was supplied from the Japan Alps in central Japan (e.g., Kimura et al. 2008; Moore et al. 2015). The mountain building in central Japan was a result of the collision between southwest and northeast Japan, which is now ascribed to the collision of the Amurian Plate with the Okhotsk or North American Plate (Wei and Seno 1998; Heki et al. 1999; Miyazaki and Heki 2001; Argus et al. 2011). Additionally, the northward indentation and collision of the Izu Peninsula has been enhanced in central Japan (Niitsuma 1989). The convergent boundary zone 
between the Amurian and the North America or Okhotsk plates is mainly along the eastern margin of the Japan Sea (Tamaki and Honza 1985; Okamura et al. 2007) and started E-W compressive tectonics from 3$2 \mathrm{Ma}$ along the margin (Okamura et al. 2007). This event was synchronous with the initiation of mountain building in central Japan and the sediment influx to the Kumano Basin and Nankai Trough (e.g., Kimura et al. 2008; Strasser et al. 2009; Moore et al. 2015). The appearance of oblique subduction-related tectonics on land, as represented by the dextral Median Tectonic Line (MTL), were also at $\sim 2 \mathrm{Ma}$ (Okada 1973). The activity of the KBEFZ as a splay fault started at $\sim 2 \mathrm{Ma}$ and the sense of slip of the KBEFZ associates with a dextral component (Tsuji et al. 2014b). The obliquity increased because of the additional eastward motion of southwest Japan associated with the onset of the Amurian/ Okhotsk Plate boundary (Fig. 7).

Thus, the tectonic events at $\sim 6$ and $\sim 2$ Ma were synchronous in the eastern Asia and Philippine Sea regions. More detailed dating of all the events at a 100-10 Ka timescale and investigation of the quantitative causal relationship are significant targets of geodynamic research in this region.

\section{Onset of the seismogenic megathrust and tectonic history}

The control of earthquake rupture areas in a subduction zone megathrust is among the most fundamental questions in geodynamic research. In the case of the Nankai Trough, three major controlling factors have been proposed thus far: the surface topography of the subducting plate, such as seamounts (Kodaira et al. 2000); a locally dense and rigid upper plate because of igneous rock composition (Kodaira et al. 2006) other than an ancient accretionary complex (Taira et al. 1988); and frictional properties of the plate boundary megathrust with abnormal pore fluid pressure (e.g., Moore and Saffer 2001; Tsuji et al. 2014a). Kimura et al. (2018) recently proposed that the middle Miocene igneous rocks of the hanging wall in southwest Japan control the rupture area of the seismogenic megathrust in the Nankai Trough and emphasized the significance of tectonic hysteresis of the upper plate. The accretionary prism that has developed since $\sim 6$ and $\sim 2 \mathrm{Ma}$ works as an upper plate wherein elastic strain energy is stored, perhaps releasing in a great tsunamigenic earthquake. The hanging wall of the inner wedge is composed of rock with an abnormally high seismic velocity (e.g., Kamei et al. 2013). The geologic component of the hanging wall is either old basement or a young but extremely over-consolidated accretionary prism, which will be soon clarified by the deep drilling of the IODP NantroSEIZE program. The accretionary prism of the transition zone between the $\sim 6$ million year (m.y.) old inner and $\sim 2$ m.y. old outer wedges and the megathrust-particularly beneath the outer accretionary prism-is the location where shallow slow earthquakes occur (Obara and Kato 2017). The plate boundary megathrust of the slow earthquakes (Araki et al. 2017; Tsuji et al. 2017) is within a low seismic velocity zone (Park et al. 2010; Kamei et al. 2013). The results of the drilling of the IODP NantroSEIZE and the tectonic history described in this study suggest that the component of the megathrust is underthrust sediments with abnormal fluid pressure starting at $\sim 2 \mathrm{Ma}$, as first inferred by Moore and Saffer (2001).

\section{Conclusions}

Seismic reflection studies coupled with drilling results have concluded that two episodes have controlled the recent evolution of the Nankai forearc: a resurgence of subduction at $\sim 6 \mathrm{Ma}$ after cessation since $\sim 12 \mathrm{Ma}$ and the rapid growth of an accretionary prism since $\sim 2 \mathrm{Ma}$ caused by a large influx of terrigenous sediments from the Japan Alps in central Japan.

This conclusion is supported by the following observations and considerations:

1) The geological sequences of the northern margin of the Kumano Basin are composed of unit 1, which is younger than the 0.9 m.y. old, forearc basin-filling sediments; unit 2-1 and unit 2-2, deposited from $\sim 3.7$ to $\sim 1.2 \mathrm{Ma}$ as slope basin sediments; and unit 3, deposited from $\sim 6$ to $3.75 \mathrm{Ma}$ as the lowest slope basin sediments. Each unit is separated by the unconformities of US1 and US2. Unit 3 unconformably (US3) overlies the accretionary prism at $\sim 7 \mathrm{Ma}$ and the old basement of middle Miocene igneous rocks or the early Miocene accretionary complex.

2) The deposition of the sediments progressed along with the tectonic deformation of the forearc. The start of the slope deposition above the accretionary prism at $\sim 6 \mathrm{Ma}$ suggests the start of accretion and subduction. The broad unconformity of US1 suggests the formation of the Kumano Basin since $\sim 2 \mathrm{Ma}$, and deposition reached to the northern margin of the basin at $\sim 0.9 \mathrm{Ma}$ as a result of northern onlapping.

3) Both episodes at $\sim 6$ and $\sim 2$ Ma were synchronous with regional plate reorganizations. The westward subduction of the PS Plate initiated both in the Ryukyu and the Philippine trenches at $\sim 6 \mathrm{Ma}$. Rifting in the Okinawa and Mariana troughs started at $\sim 6 \mathrm{Ma}$. Compressive tectonics in Northeast Japan started at $\sim 3-2 \mathrm{Ma}$, and resultant mountain building with active surface erosion commenced in 
central Japan at $\sim 2 \mathrm{Ma}$. This recent compressive tectonic phase might be a result of the eastward migration of the Amurian Plate and convergence with the Okhotsk or North America plates. In addition to this event, the strong collision and indentation of the Izu-Bonin Arc since $~ 2.5 \mathrm{Ma}$ has also been enhanced in central Japan.

\section{Abbreviations}

2D: Two-dimensional; 3D: Three-dimensional; IODP: Integrated Ocean Drilling Program before 2012 and International Ocean Discovery Program since 2013; KBEFZ: Kumano Basin Edge Fault Zone; NantroSElZE: Nankai Trough Seismogenic Zone Experiments; PS: Philippine Sea

\section{Acknowledgements}

We thank Kyoko Tonegawa for her assistance in this study. We also thank the many scientists who joined the IODP NantroSEIZE experiments both abroad and shore-based for helpful discussions. We appreciate two anonymous reviewers whose comments improved the manuscript.

\section{Funding}

This work was supported by the Japan Society for the Promotion of Science Grants-in-Aid for Scientific Research (KAKENHI) Grant Number 12345678. HK was partly funded by $A B C$ project (ABC-123-456).

\section{Declarations}

Original seismic profile (image file) can be shared. If you use the original seismic data, please contact author for data requests.

\section{Authors' contributions}

GK proposed the topic and conceived and designed the study. HK conducted the calculation of the plate kinematics. TT analyzed the seismic data and helped in its interpretation. All authors read and approved the final manuscript

\section{Competing interests}

The authors declare that they have no competing interest.

\section{Publisher's Note}

Springer Nature remains neutral with regard to jurisdictional claims in published maps and institutional affiliations.

\section{Author details}

'Department of Marine Environment and Resources, Tokyo University of Marine Science and Technology, Shinagawa, Minato-ku, Tokyo 108-8477, Japan. ${ }^{2}$ Atmosphere and Ocean Research Institute, The University of Tokyo, Kashiwa, Chiba 277-8564, Japan. ${ }^{3}$ International Institute for Carbon-Neutral Energy Research, Kyushu University, Fukuoka 819-0395, Japan.

Received: 9 May 2018 Accepted: 23 October 2018

Published online: 21 November 2018

\section{References}

Araki E, Demian M, Kopf AJ, Wallace L, Kimura M, Machida T, Yuya IS, Earl D, Expedition 348 IODP (2017) Recurring and triggered slow-slip events near the trench at the Nankai Trough subduction megathrust. Science 356(6343):1157-1160

Argus DF, Gordon RG, DeMets C (2011) Geologically current motion of 56 plates relative to the no-net-rotation reference frame. Geochem Geophys Geosy 12(11). https://doi.org/10.1029/2011GC003751.

Ashi J, Lallemant S, Masago H, the Expedition 315 Scientists (2009) Expedition 315 summary. In: Kinoshita M, Tobin H, Ashi J, Kimura G, Lallemant S, Screaton EJ, Curewitz D, Masago H, Moe KT, the Expedition 314/315/316 Scientists (eds) . Proc. IODP, 314/315/316, Washington, DC. https://doi.org/10. 2204/iodp.proc.314315316.121.2009.

Boston B, Moore GF, Jurado MJ, Sone H (2016) Deformation of the Nankai Trough inner accretionary prism: the role of inherited structures. Geochem Geophys Geosy 17(2):485-500. https://doi.org/10.1002/2015GC006185.

Chhun C, Kioka A, Jia J, Tsuji T (2018) Characterization of hydrate and gas reservoirs in plate convergent margin by applying rock physics to high-resolution seismic velocity model. Mar Petrol Geol 92:719-732. https://doi.org/10.1016/j. marpetgeo.2017.12.002.

Clift PD, Carter A, Nicholson U, Masago H (2013) Zircon and apatite thermochronology of the Nankai Trough accretionary prism and trench, Japan: sediment transport in an active and collisional margin setting. Tectonics 32:377-395.

DeMets C, Gordon RG, Argus DF (2010) Geologically current plate motion. Geophys J Int 181(1):1-80

Expedition 316 Scientists (2009) Expedition 316 Site C0006. In: Kinoshita M, Tobin H, Ashi J, Kimura G, Lallemant S, Screaton EJ, Curewitz D, Masago H, Moe KT, the Expedition 314/315/316 Scientists (eds). Proc. IODP, 314/315/316, Washington DC. https://doi.org/10.2204/iodp.proc.314315316.134.2009.

Expedition 319 Scientists (2010) Expedition 319 summary. Saffer D, McNeill L, Byrne T, Araki E, Toczko S, Eguchi N, Takahashi K, the Expedition 319 Scientists (ed) Proc. IODP, 319: Tokyo. https://doi.org/10.2204/iodp.proc.319.101.2010.

Faccenna C, Holt AF, Becker TW, Lallemand S, Royden LH (2017) Dynamics of the Ryukyu/Izu-Bonin-Marianas double subduction system. Tectonophysics. https://doi.org/10.1016/j.tecto.2017.08.011.

Gulick SP, Bangs NL, Moore GF, Ashi J, Martin KM, Sawyer DS, Tobin HJ, Kuramoto S, Taira A (2010) Rapid forearc basin uplift and megasplay fault development from 3D seismic images of Nankai Margin off Kii Peninsula, Japan. Earth Planet Sci Lett 300(1):55-62.

Hall R (2002) Cenozoic geological and plate tectonic evolution of SE Asia and the SW Pacific: computer-based reconstructions, model and animations. J Asian Earth Sci 20(4):353-431.

Heki K, Miyazaki S, Takahashi H, Kasahara M, Kimata F, Miura S, Vasilenko NF, Ivashchenko A, An KD (1999) The Amurian Plate motion and current plate kinematics in eastern Asia. J Geophys Res 104(29):147-155.

Heuret A, Lallemand S (2005) Plate motions, slab dynamics and back-arc deformation. Phys Earth Planet Inter 149(1):31-51.

Hisatomi K (1981) Geology and sedimentology of the Kumano Group in the southeastern part of the Kumano Basin, Kii Peninsula. J Geol Soc Japan 87: 157-174.

Hussong DM, Uyeda S (1982) Tectonic processes and the history of the Mariana arc: a synthesis of the results of Deep Sea Drilling Project Leg 60. In: Proceedings of Deep Sea Drilling Project Leg 60, initial reports, vol 60. College Station, pp 909-929. https://doi.org/10.2973/dsdp.proc.60.154.1982.

Jolivet L, Faccenna C, Becker T, Tesauro M, Sternai P, Bouihol P (2018) Mantle flow and deforming continents: from India-Asia convergence to Pacific subduction. Tectonics. https://doi.org/10.1029/2018TC005036.

Kamata H, Kodama K (1999) Volcanic history and tectonics of the southwest Japan arc. Island Arc 8(3):393-403.

Kamei R, Pratt R, Tsuji T (2013) On acoustic waveform tomography of wide-angle OBS data—strategies for pre-conditioning and inversion. Geophys I Int 194:1250-1280.

Karig DE (1971) Origin and development of marginal basins in the western Pacific. J Geophys Res 76:2542-2561.

Kimura G, Hashimoto Y, Kitamura Y, Yamaguchi A, Koge H (2014) Middle Miocene swift migration of the $\Pi \pi$ triple junction and rapid crustal growth in southwest Japan: a review. Tectonics 33:1219-1238.

Kimura G, Kitamura Y, Hashimoto Y, Yamaguchi A, Shibata T, Ujiie K, Okamoto S (2007) Transition of accretionary wedge structures around the up-dip limit of the seismogenic subduction zone. Earth Planet Sci Lett 255:471-484.

Kimura G, Kitamura Y, Yamaguchi A, Raimberg H (2008) Links among mountain building, surface erosion, and growth of an accretionary prism in a subduction zone - an example from southwest Japan. Geol Soc Am Spec Paper 436:391.

Kimura G, Moore GF, Strasser M, Screaton E, Curewitz D, Streiff C, Tobin H (2011) Spatial and temporal evolution of the megasplay fault in the Nankai Trough. Geochem Geophys Geosy 12(3). https://doi.org/10.1029/2010GC003335.

Kimura G, Yamahguchi A, Kinoshita M (2018) Upper plate tectonic hysteresis and segmentation of the rupture area during seismogenesis in subduction zones - a case study of the Nankai Trough. Geol Soc Am Spec Paper 534:87-99.

Kimura Jl, Stern RJ, Yoshida T (2005) Reinitiation of subduction and magmatic responses in SW Japan during Neogene time. Geol Soc Am Bull 117:969-986.

Kodaira S, Hori T, Ito A, Miura S, Fujie G, Park JO, Baba T, Sakaguchi H, Kaneda Y (2006) A cause of rupture segmentation and synchronization in the Nankai Trough revealed by seismic imaging and numerical simulation. J Geophys Res Solid Earth 111:B09301. https://doi.org/10.1029/2005JB004030.

Kodaira S, Takahashi N, Nakanishi A, Miura S, Kaneda Y (2000) Subducted seamount imaged in the rupture zone of the 1946 Nankaido earthquake. Science 289:104-106. 
Marshak RS, Karig DE (1977) Triple junctions as a cause for anomalously near trench igneous activity between the trench and volcanic arc. Geology 5:233-236.

Martin KM, Gulick SPS, Bangs NLB, Moore GF, Ashi J, Park JO, Kuramoto S, Taira A (2010) Possible strain partitioning structure between the Kumano fore-arc basin and the slope of the Nankai Trough accretionary prism. Geochem Geophys Geosy 11(5). https://doi.org/10.1029/2009GC002668.

Miura D, Wada Y (2007) Middle Miocene ash-flow calderas at the compressive margin of southwest Japan arc: review and synthesis. J Geol Soc Japan 113:283-295.

Miyazaki S, Heki K (2001) Crustal velocity field of southwest Japan: subduction and arc-arc collision. J Geophys Res Solid Earth (1978-2012) 106(B3):4305-4326.

Moore GF, Boston BB, Strasser M, Underwood MB, Ratliff RA (2015) Evolution of tectono-sedimentary systems in the Kumano Basin, Nankai Trough forearc. Mar Petrol Geol 67:604-616.

Moore GF, Park JO, Bangs NL, Gulick SP, Tobin HJ, Nakamura Y, Sato S, Tsuji T, Yoro T, Tanaka H, Urakki S, Kido Y, Sanada Y, Kuramoto S, Taira A (2009) Structural and seismic stratigraphic framework of the NanTroSEIZE stage 1 transect. In: Proceedings IODP, 314(315/316). https://doi.org/10.2204/iodp. proc.314315316.102.2009.

Moore GF, Strasser M (2016) Large mass transport deposits in Kumano Basin, Nankai Trough, Japan. In: Lamarche G, Mountjoy J, Bull S, Hubble T, Krastel S, Lane E, Micallef A, Moscardelli L, Mueller C, Pecher I, Woelz S (eds) Submarine mass movements and their consequences 7 th international symposium. Springer, Cham, pp 371-379.

Moore JC, Saffer D (2001) Updip limit of the seismogenic zone beneath the accretionary prism of southwest Japan: an effect of diagenetic to low-grade metamorphic processes and increasing effective stress. Geology 29:183-186.

Morita S, Ashi J, Aoike K, Kuramoto S (2004) Evolution of Kumano basin and sources of clastic ejecta and pore fluid in Kumano mud volcanoes, Eastern Nanaki Trough. In: Proceedings of the international symposium on methane hydrates and fluid flow in upper accretionary prisms. Engineering Geology Laboratory, Department of Civil \& Earth Resources Engineering, Kyoto University, Kyoto, pp 92-99.

Niitsuma N (1989) Collision tectonics in the South Fossa magna, central Japan. Mod Geol 14:3-18.

Obara K, Kato A (2017) Connecting slow earthquakes to huge earthquakes. Science 353(6296):253-257.

Okada A (1973) On the Quaternary faulting along the Median Tectonic Line. In: Median Tectonic Line, pp 49-86.

Okamura Y, Ishiyama T, Yanagisawa Y (2007) Fault-related folds above the source fault of the 2004 mid-Niigata Prefecture earthquake, in a fold-and-thrust belt caused by basin inversion along the eastern margin of the Japan Sea. J Geophys Res 112:B03S08. https://doi.org/10.1029/2006JB004320.

Park JO, Fujie G, Wijerathne L, Hori T, Kodaira S, Fukao Y, Moore GF, Bangs NL, Kuramoto S, Taira A (2010) A low-velocity zone with weak reflectivity along the Nankai subduction zone. Geology 38:283-286.

Pickering KT, Underwood MB, Saito S, Naruse H, Kutterolf S, Scudder R, Park J-O, Moore GF, Slagle A (2013) Depositional architecture, provenance, and tectonic/eustatic modulation of Miocene submarine fans in the Shikoku Basin: results from Nankai Trough Seismogenic zone experiment. Geochem Geophys Geosyst 14:1722-1739. https://doi.org/10.1002/ggge.20107.

Saffer D, McNeill L, Araki E, Byrne T, Equchi N, Toczko S, Takahashi K (2009) NanTroSEIZE stage 2: NanTroSEIZE riser/riserless observatory. IODP Preliminary Report 319(82).

Sakuyama T, Ozawa K, Sumino H, Nagao K (2009) Progressive melt extraction from upwelling mantle constrained by the Kita-Matsuura basalts in NW Kyushu, SW Japan. J Petrol 50(4):725-779.

Screaton EJ, Kimura G, Curewitz D, Moore G, Chester F, Fabbri O, Fergusson C, Girault F, Goldsby D, Harris R, Inagaki F, Jiang T, Kitamura Y, Knuth M, Li CF, Liljedahl LC, Louis L, Milliken K, Nicholson U, Riedinger N, Sakaguchi A, Solomon E, Strasser M, Su X, Tsutsumi A, Yamaguchi A, Ujie K, Zhao X (2009) Interactions between deformation and fluids in the frontal thrust region of the NanTroSEIZE transect offshore the Kii Peninsula, Japan: results from IODP Expedition 316 Sites C0006 and C0007. Geochem Geophys Geosy 10(12). https://doi.org/10.1029/2009GC002713.

Seton M, Flament N, Whittaker J, Müller RD, Gurnis M, Bower DJ (2015) Ridge subduction sparked reorganization of the Pacific plate-mantle system 60-50 million years ago. Geophys Res Lett 42:1732-1740.

Strasser M, Moore GF, Kimura G, Kitamura Y, Kopf AJ, Lallemant S, Park J-O, Screaton EJ, Su X, Underwood MB (2009) Origin and evolution of a splay fault in the Nankai accretionary wedge. Nat Geosci 2:648-652.
Suppe J (1981) Mechanics of mountain building and metamorphism in Taiwan. Mem Geol Soc China 4:67-89.

Suzuki H (2012) Structural features of the Shimanto Accretionary Prism in the Kii Peninsula. Assoc Geol Collab Japan Monogr 59:101-110 (in Japanese with an English abstract).

Tagami T, Hasebe N, Shimada C (1995) Episodic exhumation of accretionary complexes: fission-track thermochronologic evidence from the Shimanto Belt and its vicinities, southwest Japan. Island Arc 4:209-230.

Taira A, Katto J, Tashiro M, Okamura M, Kodama K (1988) The Shimanto Belt in Shikoku, Japan-Evolution of Cretaceous to Miocene accretionary prism. Mod Geol 12:5-46.

Tamaki K, Honza E (1985) Incipient subduction and deduction along the eastern margin of the Japan Sea. Tectonophysics 119:381-406.

Tapponnier P, Peltzer G, LeDain AY, Armijo R, Cobbold P (1982) Propagating extrusion tectonics in Asia: new insights from simple experiments with plasticine. Geology 10:611-616.

Tatsumi Y, Maruyama S, Nohda S (1990) Mechanism of backarc opening in the Japan Sea: role of asthenospheric injection. Tectonophysics 181(1-4):299-306.

Tobin HJ, Kinoshita M (2006) NanTroSElZE: the IODP Nankai Trough seismogenic zone experiment. Sci Drill 2:23-27.

Tsuji T, Ashi J, Ikeda Y (2014b) Strike-slip motion of a mega-splay fault system in the Nankai oblique subduction zone. Earth Planet Space 66(1):120-134.

Tsuji T, Ashi J, Strasser M, Kimura G (2015) Identification of the static backstop and its influence on the evolution of the accretionary prism in the Nankai Trough. Earth Planet Sci Lett 431:15-25.

Tsuji T, Kamei R, Pratt RG (2014a) Pore pressure distribution of a mega-splay fault system in the Nankai Trough subduction zone: insight into up-dip extent of the seismogenic zone. Earth Planet Sci Lett 396:165-178.

Tsuji T, Minato S, Kamei R, Tsuru T, Kimura G (2017) 3D geometry of a plate boundary fault related to the 2016 Off-Mie earthquake in the Nankai subduction zone, Japan. Earth Planet Sci Lett 478:234-244.

Underwood MB (2018) The origin of strata within the inner accretionary prism of Nankai Trough: evidence from clay mineral assemblages along the NanTroSEIZE transect. Island Arc 27(3):e12252.

Underwood MB, Moore GF (2012) Evolution of sedimentary environments in the subduction zone $V$ of southwest Japan: recent results from the NanTroSEIZE Kumano Transect. In: Tectonics of sedimentary basins: recent advances, pp 310-328.

Uyeda S, Kanamori H (1979) Back-arc opening and the mode of subduction. J Geophys Res 84(B3):1049-1061.

Wei D, Seno T (1998) Determination of the Amurian plate motion. In: Mantle dynamics and plate interactions in East Asia, AGU Geodynamic Series, vol 27, pp 337-346.

Wu J, Suppe J, Lu R, Kanda R (2016) Philippine Sea and East Asian plate tectonics since $52 \mathrm{Ma}$ constrained by new subducted slab reconstruction methods. J Geophys Res Solid Earth 121. https://doi.org/10.1002/2016JB012923.

Yamazaki T, Seama N, Okino K, Kitada K, Joshima M, Oda H, Naka (2003) Spreading process of the northern Mariana Trough: rifting-spreading transition at 22_N. Geochem Geophys Geosyst 4(9):1075. https://doi.org/10. 1029/2002GC000492

\section{Submit your manuscript to a SpringerOpen ${ }^{\odot}$ journal and benefit from:}

- Convenient online submission

- Rigorous peer review

- Open access: articles freely available online

High visibility within the field

- Retaining the copyright to your article

Submit your next manuscript at $>$ springeropen.com 